\title{
Analisis Sejarah, Dampak, Dan Penanggulangan Bencana Gempa Bumi Pada Saat Pandemi Covid-19 Di Sulawesi Barat

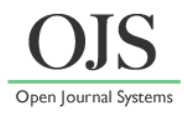

\author{
Dedy Hartono*, Rio Khoirudin Apriyadi, Tri Winugroho, Aprilyanto, Siswo Hadi \\ Sumantri, Wilopo, Hafizh Surya Islami \\ Program Studi Manajemen Bencana, Fakultas Keamanan Nasional, Universitas Pertahanan \\ *Email: dedyhartonoaal50@gmail.com
}

DOI: https://doi.org/10.33369/pendipa.5.2.218-224

\begin{abstract}
[Analysis of the History, Impact and Management of Earthquake Disaster during the Covid-19 Pandemic in West Sulawesi] Geographical, demographic, sociological, meteorological and climatological conditions of Indonesia make Indonesia in a disaster-prone area (natural, non-natural, and social). This condition can be used as a laboratory to produce disaster experts, knowledge and technology in Indonesia. Law 24/2007 as a framework for disaster management systems in Indonesia currently prioritizes the disaster mitigation paradigm so that a strong commitment and participation of all parties is needed to build and run this system properly. However, currently Indonesia is faced with multiple disasters that occurred during the Covid-19 pandemic. This is supported by data on the earthquake disaster in West Sulawesi on January 15, 2021 which occurred amid the potential for the spread of Covid-19 infection. The character of the risk in this problem is how to minimize the time for evacuation, emergency response and recovery of community conditions without neglecting the potential for transmission of Covid-19 infection. This study uses a descriptive quantitative approach with secondary data in the form of BNPB volunteer desks, BNPB current situation reports and population data and civil records. The data analysis technique uses quantitative methods through univariate analysis. The results showed that the history of disaster recorded that in West Sulawesi, there had been an M 6 RS earthquake in 1820, 1976, 1969, 1984 and 2021. The earthquake of January 15, 2021 occurred at 01.28.17 WIB with a magnitude of M 6.2 RS at depth of $10 \mathrm{~km}$ with the location: $2.98 \mathrm{LS}, 118.94 \mathrm{BT}$ (6 km northeast of Majene). The potential affected population in Majene Regency is 59,543 people, Mamasa Regency 62,007 people, Mamuju Regency 144,377 people, Polewali Mandar Regency 219,305 people. Quick response was shown by Indonesia through the President's direction to BNPB, Ministry of Social Affairs, Basarnas, TNI and Kapolri and their staff to take emergency response steps as soon as possible through Emergency Response Status No.001 / Darurat-SB / I / 2021 which is valid for 14 days (15-28 January 2021). The seventh main sectors in the emergency response are search and rescue, logistics or soup kitchens, shelters, mapping, clean water, sanitation and hygiene, communication and health.
\end{abstract}

Keywords: History; Impact; Earthquake; Covid-19.

\begin{abstract}
ABSTRAK
Kondisi geografis, demografis, sosiologis, meteorologis dan klimatologis Indonesia menjadikan Indonesia berada di daerah rawan terhadap bencana (alam, non alam, dan sosial). Kondisi ini dapat dimanfaatkan sebagai laboratorium untuk menghasilkan tenaga ahli, pengetahuan dan teknologi kebencanaan di Indonesia. UU 24/2007 sebagai kerangka sistem penanggulangan bencana di Indonesia saat ini telah mengutamakan paradigma mitigasi bencana sehingga diperlukan komitmen yang kuat dan partisipasi semua pihak untuk membangun dan menjalankan sistem ini dengan baik. Namun saat ini Indonesia dihadapkan pada multi bencana yang terjadi pada saat pandemi Covid-19. Hal ini didukung oleh data kejadian bencana gempa bumi di Sulawesi Barat pada tanggal 15 Januari 2021 yang terjadi di tengah potensi penyebaran infeksi Covid-19. Karakter risiko pada permasalahan ini adalah bagaimana meminimalkan
\end{abstract}


waktu evakuasi, tanggap darurat dan pemulihan kondisi masyarakat tanpa mengesampingkan potensi penularan penularan infeksi Covid-19. Penelitian ini menggunakan pendekatan kuantitatif deskriptif dengan data sekunder berupa desk relawan BNPB, laporan situasi terkini BNPB dan data kependudukan dan catatan sipil. Teknik analisa data menggunakan metode kuantitatif melalui analisa univariat. Hasil Penelitian menunjukkan bahwa sejarah kebencanaan mencatat bahwa di Sulawesi Barat pernah terjadi gempa bumi $M \geq 6$ SR pada tahun 1820, 1976, 1969, 1984 dan 2021. Gempa bumi 15 Januari 2021 terjadi pukul 01.28.17 WIB dengan kekuatan M 6,2 SR pada kedalaman $10 \mathrm{~km}$ dengan lokasi : 2.98 LS, 118.94 BT (6 km timur laut Majene). Potensi penduduk terdampak di Kabupaten Majene berjumlah 59.543 jiwa, Kabupaten Mamasa 62.007 jiwa, Kabupaten Mamuju 144.377 jiwa, Kabupaten Polewali Mandar 219.305 jiwa. Respon cepat ditunjukkan oleh Indonesia melalui arahan Presiden kepada BNPB, Kemensos, Basarnas, TNI dan Kapolri beserta jajarannya agar melakukan langkah tanggap darurat secepatnya melalui Status Tanggap Darurat No.001/Darurat-SB/I/2021 yang berlaku selama 14 hari (15-28 Januari 2021). 7 sektor utama dalam tanggap darurat tersebut adalah pencarian dan pertolongan, logistik atau dapur umum, shelter, pemetaan, air bersih, sanitasi dan hygiene, komunikasi serta kesehatan.

Kata kunci: Sejarah; Dampak; Gempa Bumi; Covid-19.

\section{PENDAHULUAN}

Dinamika geografis, demografis, sosiologis, meteorologis dan klimatologis Indonesia selain menjadikan Indonesia kaya akan sumber daya alam, namun juga menjadikan Indonesia rawan terhadap bencana (alam, non alam, dan sosial). Kondisi ini dapat dimanfaatkan sebagai laboratorium (Rahmad, 2019) untuk menghasilkan tenaga ahli, pengetahuan dan teknologi kebencanaan di Indonesia. (Rusilowati, Binadja, \& Mulyani, 2012).

Sejarah kebencanaan di Indonesia menunjukkan bahwa jumlah kejadian dan korban bencana semakin meningkat dan kompleks, (Jati, 2015) (Adi, 2014), sehingga hal ini memerlukan sistem penanggulangan bencana dan manejemen risiko bencana yang handal. (Ahdi, 2015).

UU 24/2007 sebagai kerangka sistem penanggulangan bencana di Indonesia saat ini (RI, 2007) telah mengutamakan paradigma mitigasi bencana sehingga diperlukan komitmen yang kuat dan partisipasi semua pihak (Prasetio, Arifianti, Hardjakaprabon, \& Agustin, 2012) untuk membangun dan menjalankan sistem ini dengan baik.

Mitigasi bencana adalah pengurangan risiko bencana diluar kemampuan masyarakat, (Akhirianto, 2019), karena ancaman dan bahaya hanya menjadi bencana jika berdampak pada masyarakat yang rentan. (Widayatun \& Fatoni, 2013).

Masyarakat disamping sebagai key element dalam menghadapi bencana, juga merupakan end to end penanggulangan bencana. (Maarif, 2012).
Artinya apapun upaya dalam penanggulangan bencana harus bermuara pada pengetahuan modern (Sosiawan, 2015) dan kearifan lokal masyarakat. (Sukmana, 2018).

Namun saat ini Indonesia dihadapkan pada kejadian bencana yang terjadi pada saat pandemi Covid-19 (multi hazard). (Apriyadi \& Amelia, 2020). Hal ini didukung oleh data kejadian bencana seperti gempa bumi di Sulawesi Barat pada tanggal 15 Januari 2021 yang terjadi di tengah penyebaran infeksi Covid-19.

Karakter risiko bencana ini adalah bagaimana meminimalkan waktu evakuasi, tanggap darurat dan pemulihan kondisi masyarakat tanpa mengesampingkan potensi penularan Covid-19. (Herdiana, 2020).

Sesuai arahan Presiden maka BNPB, Kemensos, Basarnas, TNI dan Kapolri beserta jajarannya diperintahkan agar melakukan langkah tanggap darurat dengan prioritas mencari dan menemukan korban, perawatan kepada korban luka, dan memulihkan kondisi masyarakat secepat mungkin dengan sumber daya nasional tetapi tetap mengikuti protokol kesehatan yang berlaku. (Humas, 2021).

Untuk itu diperlukan manajemen resiko yang mengatur hal-hal tersebut agar tidak menjadi fatal dikemudian hari. (Subagia, Santoso, Maryanti, \& Ramadhani, 2020), Maka, penelitian ini akan menghasilkan alat bantu bagi stakeholder dalam mengambil keputusan (Decision Support System) pada saat bencana terjadi dan dalam pelaksanaan proses evakuasi ketika bencana tersebut terjadi 
pada saat pandemi Covid-19. (Apriyadi \& Amelia, 2020).

Berdasarkan uraian masalah diatas, maka penelitian dengan judul "Analisis Sejarah, Dampak, dan Penanggulangan Bencana Gempa Bumi Pada Saat Pandemi Covid-19 di Sulawesi Barat" perlu dilakukan. Penelitian ini berkontribusi pada pengetahuan terkini tentang sejarah, dampak, dan penanggulangan bencana gempa bumi pada saat pandemi Covid-19 di Sulawesi Barat.

\section{METODE PENELITIAN}

Penelitian ini menggunakan pendekatan kuantitatif deskriptif yang bertujuan untuk menganalisis dan mendeskripsikan sejarah, dampak, dan penanggulangan bencana gempa bumi pada saat pandemi Covid-19 di Sulawesi Barat. Sumber Data penelitian ini adalah data sekunder yang berupa desk relawan BNPB (BNPB, 2021a), laporan situasi terkini BNPB (BNPB, 2021b) dan data kependudukan dan catatan sipil.

Teknik analisa data menggunakan metode kuantitatif melalui analisa univariat. Analisis Univariat dilakukan pada setiap variabel dalam penelitian ini. Tujuan dari analisis ini adalah untuk melihat distribusi frekuensi dari setiap variabel yang diteliti. Hasil analisis penelitian disajikan dalam bentuk gambar dan tabel distribusi frekuensi untuk memudahkan interpretasi sebagai temuan penelitian. Penelitian ini berkontribusi pada pengetahuan terkini tentang sejarah, dampak, dan penanggulangan bencana gempa bumi pada saat pandemi Covid-19 di Sulawesi Barat.

\section{HASIL DAN PEMBAHASAN}

Sejarah Gempa Bumi Sulawesi Barat.

Sejarah Kebencanaan mencatat bahwa bencana gempa bumi yang terjadi di Sulawesi Barat pada tanggal 15 Januari 2021 bukanlah yang pertama kali terjadi, Sulawesi Barat setidaknya pernah terjadi gempa bumi $\mathrm{M} \geq 6$ SR terjadi pada tahun 1820, 1969, 1976, 1984 seperti yang ditunjukkan pada tabel 1 .

Tahun 1820 terjadi gempa disertai tsunami di wilayah Makassar, 11 April 1976 terjadi gempa M 6,3 SR yang menimbulkan Tsunami dan menyebabkan 13 orang meninggal di Polewali Mandar, 23 Februari 1969 terjadi gempa M 6,9 SR kedalaman $13 \mathrm{~km}$ menyebabkan tsunami setinggi $4 \mathrm{~m}$ hingga $100 \mathrm{~m}$ mengakibatkan 64 orang meninggal dan hilang, 97 orang luka-luka, 1.287 rumah rusak di Kecamatan Malunda, 8 Januari 1984 terjadi gempa M 6,7 SR menyebabkan ratusan korban jiwa di Kabupaten Majene dan Mamuju, 15 Januari 2021 terjadi gempa M 6,2 SR mengakibatkan 46 orang meninggal dunia, 826 Luka-luka, dan sekitar 15.000 orang mengungsi di Kabupaten Majene dan Mamuju.

Tabel 1. Sejarah bencana gempa bumi di Sulawesi Barat pada periode tahun 1820 sd 2021.

\begin{tabular}{ll}
\hline \multicolumn{1}{c}{ Tahun } & \multicolumn{1}{c}{ Jenis Bencana } \\
\hline 1820 & Gempa bumi disertai tsunami \\
23 Februari 1969 & Gempa bumi disertai tsunami \\
11 April 1976 & $\begin{array}{l}\text { Gempa bumi disertai tsunami } \\
\text { 8 Januari 1984 }\end{array}$ \\
15 Januari 2021 & $\begin{array}{l}\text { Gempa bumi } \\
\text { tsunami }\end{array}$ \\
\hline
\end{tabular}

Kronologis Dan Perkembangan Terkini Gempa Bumi Sulawesi Barat Tahun 2021.

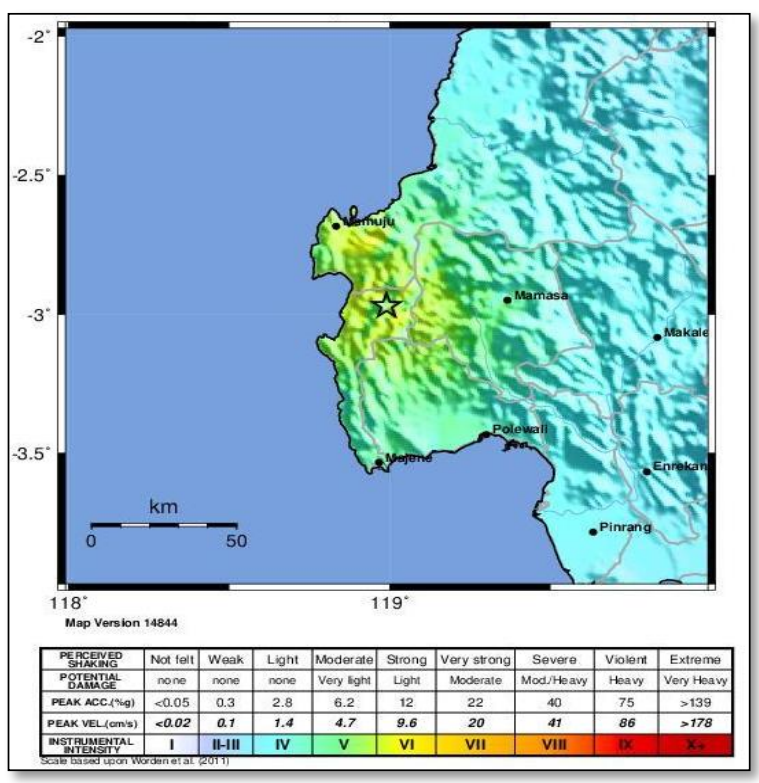

Gambar 1. Peta guncangan (shakemap) gempa bumi Sulawesi Barat 15 Januari 2021

Kronologis kejadian telah terjadi gempa bumi sebanyak 2 kali (besar) yaitu Kamis 14 januari 2021 dengan kekuatan M 5,9 SR pada kedalaman $10 \mathrm{~km}$ dengan lokasi : 2.99 LS, 118.89 BT (pusat gempa berada di darat $4 \mathrm{~km}$ barat laut Majene). esok harinya, Jumat, 15 Januari 2021 
pukul 01.28.17 WIB terjadi kembali gempa dengan kekuatan M 6,2 SR pada kedalaman $10 \mathrm{~km}$ dengan lokasi : $2.98 \mathrm{LS}, 118.94$ BT (6 km timur laut Majene), seperti yang ditunjukkan oleh gambar 1.

Perkembangan terkini pada tanggal 18 Januari 2021 digambarkan bahwa Kantor Gubernur Prov. Sulawesi Barat mengalami kerusakan, Swab Antigen tidak tersedia untuk screening awal pasien, Pasien yang dirawat di RS terdampak untuk sementara dievakuasi di RS Lapangan, Stok APD saat ini menipis, Klaster kesehatan saat ini sudah aktif, Semua lembaga penyalur bahan bakar minyak dan gas (SPBU, LPG dan SPBE) tidak ada yang terkena dampak gempa, sehingga pagi ini dapat beroperasi dan Melayani kebutuhan masyarakat dengan Normal.

Di Kabupaten Mamuju 3 RS yang saat ini aktif utk pelayanan kedaruratan yaitu RS Bhayangkara, RS Prov. Sulawesi Barat, dan RSUD Kab. Mamuju. Listrik di seluruh Kab. Majene masih belum dapat menyala karena masih dalam proses perbaikan. Sedangkan listrik di Kab. Mamuju hanya sebagian wilayah yang menunjukkan aliran listrik normal, sebagian wilayah lainnya masih mengalami gangguan, Jalur darat dari arah Mamuju menuju Kab. Majene belum dapat dilalui akibat Jembatan kuning masih mengalami kerusakan dan longsoran yang menutup jalan.

\section{Potensi Penduduk Terdampak Gempa Bumi Sulawesi Barat Tahun 2021.}

Dampak Kejadian gempa bumi 15 Januari 2021 ini telah mengakibatkan bencana berupa kerusakan bangunan dan korban jiwa.

Jumlah Korban di Kab. Majene terdapat 8 orang meninggal dunia (MD) dan Kab. Mamuju 34 orang (MD) Total : 42 (MD), luka berat / rawat inap sebanyak 189 orang dan luka ringan / rawat jalan berjumlah 637 orang. Jumlah pengungsi di Kab. Majene berjumlah \pm 15.000 orang mengungsi di beberapa titik pengungsian dengan potensi penduduk terdampak seperti yang digambarkan pada gambar 2 .

Berdasarkan data Dukcapil pada Juni 2020 maka potensi Jumlah Penduduk di Kabupaten Majene berjumlah 59.543 Jiwa, Kabupaten Mamasa berjumlah 62.007 Jiwa, Kabupaten
Mamuju berjumlah 144.377 Jiwa, Kabupaten Polewali Mandar berjumlah 219.305 Jiwa.

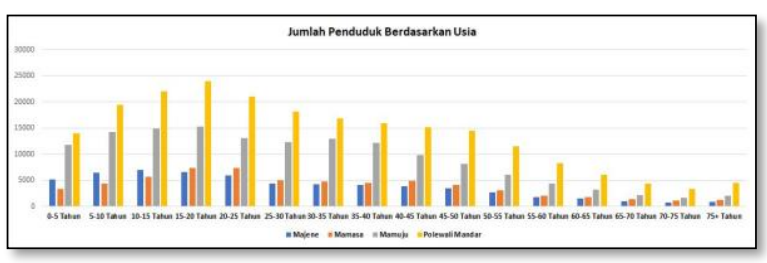

Gambar 2. Potensi penduduk terdampak

Wilayah Terdampak Kabupaten Majene sebanyak 5 Kecamatan dan 40 Desa, Kabupaten Mamasa berjumlah 9 Kecamatan dan 71 Desa, Kabupaten Mamuju berjumlah 5 Kecamatan dan 31 Desa, Kabupaten Polewali Mandar berjumlah 10 Kecamatan dan 80 Desa.

Upaya Penanganan Bencana Gempa Bumi Sulawesi Barat Tahun 2021

Berdasarkan arahan Presiden maka BNPB, Kemensos, Basarnas, TNI dan Kapolri beserta jajarannya diperintahkan agar melakukan langkah tanggap darurat dengan prioritas mencari dan menemukan korban, perawatan kepada korban luka, dan memulihkan keadaan secepat mungkin dengan sumber daya nasional. (Humas, 2021).

Hal ini direspon secara cepat oleh Gubernur Sulawesi Barat dengan menetapkan Status Tanggap Darurat Nomor : 001/Darurat-SB/I/2021 yang berlaku selama (14 hari) terhitung mulai tanggal 15 Januari 2021 sampai dengan 28 Januari 2021. (Barat, 2021).

7 sektor utama dalam tanggap darurat tersebut adalah pencarian dan pertolongan, logistik atau dapur umum, shelter, pemetaan, air bersih, sanitasi dan hygiene, komunikasi serta kesehatan.

Kebutuhan Mendesak dalam keadaan tanggap darurat ini adalah sembako, selimut dan tikar, tenda pengungsi atau tenda posko, pelayanan medis, terpal, alat berat atau excavator, alat komunikasi, makanan siap saji, masker, obatobatan gawat darurat dan vitamin, alat pelindung diri (APD), cairan infus, kassa, bidai, handscoon, masker bedah, infuset semua ukuran, benang jahit, linen sekali pakai, obat anestesi, O2 portable, hogi+set steril linen disposible, gypsona 6" 30 pcs, gypsona 4" 30 pcs, elastic verban $6 \times 4 \mathrm{ml} 30$ 
pcs, skin traksi dewasa 30 pcs, skin traksi anakanak $=30$ pcs, soft band $6 \times 4 \mathrm{ml} 30 \mathrm{pcs}$, daryantule 50 pcs, obat antibiotik oral dan injeksi, obat analgetik, heating set.

Kendala yang dihadapi pada tanggap darurat gempa bumi di Majene adalah 3 titik longsor yang berimbas pada terputusnya jalan poros mamuju ke majene dan komunikasi seluler terputus-putus serta tidak stabil

Solusi terhadap kendala diatas adalah menggunakan jalur alternatif yang aman ke Mamuju, seperti dari Makassar melewati Polewali Mandar ke arah kanan menuju Mamuju atau dari Palu melewati Pasangkayu menuju Mamuju serta dari Toraja melewati Arralle menuju Mamuju. Selain itu, pelaksanaan tanggap darurat gempa bumi Sulawesi Barat tahun 2021 dibantu oleh sejumlah relawan yang ditunjukkan oleh tabel 2 .

Tabel 2. Pemetaan Relawan Penanganan Bencana Gempa Bumi Sulawesi Barat Tahun 2021.

\begin{tabular}{lc}
\hline \multicolumn{1}{c}{ Lembaga Relawan } & Jumlah \\
\hline Adra & 2 \\
Apdi & 5 \\
Baznas & 47 \\
Bulan Sabit Merah Indonesia & 14 \\
Senkom Palu/Sulsel/Sulbat & 32 \\
Sky Volunteer-Uinspire Indonesia & 3 \\
Yayasan Inanta & 3 \\
KUN & 12 \\
Dinas Kelautan Perikanan Sulbar & - \\
Dompet Dhuafa & 21 \\
DWP Sulbar & - \\
Garuda Nusantara & 10 \\
Islamic Relief/ Karsa & 5 \\
Lazis Nurul Hayat & 4 \\
Yayasan Bone Bula & - \\
Relawan Kompala Unifa Makassar & 5 \\
LPBI NU & 100 \\
LSPR Peduli & 3 \\
Manggala Agni/ KLHK & 30 \\
MDMC & 92 \\
Nusantara Jaya Filantropi & 8 \\
Yayasan Sheep Indonesia/Yayasan & 4 \\
Bone Bula & \\
Mapala PNUP & 4 \\
&
\end{tabular}

\begin{tabular}{lc} 
Mapala Klorofil Univ Tomaka & 3 \\
PMI & 64 \\
Pramuka & 30 \\
RAPI nasional & 20 \\
Rumah Zakat & 16 \\
Sekolah Sungai Jene Barang & 3 \\
Wanadri & 10 \\
Kemendikbud Sulbar & 25 \\
\hline
\end{tabular}

Berdasarkan data Desk Relawan BNPB maka terdapat 31 lembaga relawan dengan jumlah personil 575 orang dan untuk memudahkan proses tanggap darurat maka dilakukan rapat koordinasi harian desk relawan setiap jam 16.00 WITA di DKP Sulawesi Barat.

\section{KESIMPULAN}

Berdasarkan temuan hasil penelitian dapat disimpulkan bahwa:

1. Sulawesi Barat pernah terjadi gempa bumi M $\geqq 6$ SR pada tahun 1820, 1976, 1969, 1984 dan 2021.

2. Kronologis gempa bumi pada 15 Januari 2021 terjadi pukul 01.28.17 WIB dengan kekuatan M 6,2 SR pada kedalaman $10 \mathrm{~km}$ dengan lokasi : $2.98 \mathrm{LS}, 118.94 \mathrm{BT}$ (6 km timur laut Majene).

3. Potensi penduduk terdampak di Kabupaten Majene berjumlah 59.543 jiwa, Kabupaten Mamasa 62.007 jiwa, Kabupaten Mamuju 144.377 jiwa, Kabupaten Polewali Mandar 219.305 jiwa.

4. Respon cepat ditunjukkan oleh Indonesia melalui arahan Presiden kepada BNPB, Kemensos, Basarnas, TNI dan Kapolri beserta jajarannya agar melakukan langkah tanggap darurat secepatnya melalui Status Tanggap Darurat No.001/Darurat-SB/I/2021 yang berlaku selama 14 hari (15-28 Januari 2021).

5. Tujuh sektor utama dalam tanggap darurat bencana tersebut adalah pencarian dan pertolongan, logistik atau dapur umum, shelter, pemetaan, air bersih, sanitasi dan hygiene, komunikasi serta kesehatan.

6. Hal ini menggambarkan kepada kita bahwa Sulawesi Barat berada didaerah rawan bencana gempa bumi dan tsunami, oleh karena itu diperlukan serangkaian upaya 
mitigasi untuk mengurangi risiko bencana yang kemungkinan terjadi dimasa yang akan datang. Selain itu, budaya hidup harmoni dengan bencana harus ditanamkan kepada masyarakat melalui kearifan lokal yang ada di daerah. Langkah ini perlu dipersiapkan agar kerugian materi dan non-materi bisa diminimalkan.

\section{DAFTAR PUSTAKA}

Adi, S. (2014). Karakterisasi Bencana Banjir Bandang Di Indonesia. Jurnal Sains Dan Teknologi Indonesia, 15(1). https://doi.org/10.29122/jsti.v15i1.938

Ahdi, D. (2015). Perencanaan Penanggulangan Bencana Melalui Pendekatan Manajemen Risiko. Reformasi, 5(1), 13-30. https://doi.org/10.33366/rfr.v5i1.60

Akhirianto, N. A. (2019). Konsep Desain Pengurangan Risiko Bencana Longsor Berbasis Komunitas. Jurnal Sains Dan Teknologi Mitigasi Bencana, 12(1), 32-43. https://doi.org/10.29122/jstmb.v12i1.3698

Apriyadi, R. K., \& Amelia, R. (2020). Tingkat Pengetahuan Kesiapsiagaan Resiko Bencana Tsunami disaat Pandemi Covid19. PENDIPA Journal of Science Education, 5(1), 56-62. https://doi.org/10.33369/pendipa.5.1.56-62

Barat, G. S. (2021). Surat Nomor 001/DaruratSB/I/2021 Tentang Status Tanggap Darurat Bencana Gempa Bumi Sulawesi Barat. Sulawesi Barat: Pemerintah Daerah Sulawesi Barat.

BNPB. (2021a). Dokumen Pemetaan Relawan Penanganan Bencana Gempa Sulawesi Barat (Desk Relawan BNPB 17012017) (Jakarta, Ed.). Badan Nasional Penanggulangan Bencana.

BNPB. (2021b). Update Penanganan Bencana Gempa Bumi Sulawesi Barat (17012020). Jakarta: Badan Nasional Penanggulangan Bencana.

Herdiana, D. (2020). Rekomendasi Kebijakan Pemulihan Pariwisata Pasca Wabah Corona Virus Disease 2019 (Covid-19) di Kota Bandung. Jurnal Master Pariwisata (JUMPA), 1. https://doi.org/10.24843/jumpa.2020.v07.i0 1.p01

Humas. (2021). Pemerintah Lakukan
Penanganan Darurat Bencana Gempa Bumi di Sulbar dan Banjir di Kalsel. Retrieved January 17, 2021, from https://setkab.go.id/pemerintah-lakukanpenanganan-darurat-bencana-gempa-bumidi-sulbar-dan-banjir-di-kalsel/

Jati, W. R. (2015). Bonus Demografi Sebagai Mesin Pertumbuhan Ekonomi: Jendela Peluang Atau Jendela Bencana Di Indonesia? Populasi, 23(1), 1-19. https://doi.org/10.22146/jp.8559

Maarif, S. (2012). Pikiran dan Gagasan Penanggulangan Bencana di Indonesia. Jakarta: Badan Nasional Penanggulangan Bencana.

Prasetio, E. A., Arifianti, Y., Hardjakaprabon, B., \& Agustin, F. (2012). Triple Helix in Disaster Management: Case Study of Strategic Environmental Assessment (SEA) for Government Office Relocation Planning of Padang City, Indonesia. Procedia Social and Behavioral Sciences, 52, 150159.

https://doi.org/https://doi.org/10.1016/j.sbsp ro.2012.09.451

Rahmad, R. (2019). Zonasi Ppemanfaatan Lahan Pasca Penambangan Pasir di pesisir Cipatujah, Kabupaten Tasikmalaya, Jawa Barat. Jurnal Geografi, 11(2), 171-181. https://doi.org/10.24114/jg.v11i2.10712

RI. (2007). Undang-Undang No. 24 Tahun 2007 Tentang Penanggulangan Bencana. Jakarta: Pemerintah Republik Indonesia. Rusilowati, A., Binadja, A., \& Mulyani, S. E. S. (2012). Mitigasi Bencana Alam Berbasis Pembelajaran Bervisi Science Environment Technology and Society. Jurnal Pendidikan Fisika Indonesia, 8(1). https://doi.org/10.15294/jpfi.v8i1.1994

Sosiawan, E. A. (2015). Model Ideal Manajemen Teknologi Informasi dan Komunikasi dalam Mendukung Operasional Penanganan Bencana Alam. JURNAL IPTEKKOM : Jurnal Ilmu Pengetahuan \& Teknologi Informasi, 17(2), 175. https://doi.org/10.33164/iptekkom.17.2.201 5.175-188

Subagia, D., Santoso, I. A. P., Maryanti, M., \& Ramadhani, R. M. (2020). Strategi Pengambilan Keputusan Strategis Dalam Menghadapi Pandemi Covid-19 Di 
Indonesia: Sebuah Literatur Review. Jurnal

Manajemen Bencana (JMB), 6(2).

https://doi.org/10.33172/jmb.v6i2.624

Sukmana, O. (2018). Pengetahuan Dan Nilai

Kearifan Sosial Dalam Proses Manajemen

Bencana Gunung Kelud (Studi di Desa

Pandansari, Kecamatan Ngantang,

Kabupaten Malang). Sosio Konsepsia, 7(3), 146-160.

https://doi.org/10.33007/ska.v7i3.1417
Widayatun, \& Fatoni, Z. (2013). Permasalahan Kesehatan Dalam Kondisi Bencana: Peran Petugas Kesehatan Dan Partisipasi Masyarakat. Peneliti Pusat Penelitian

Kependudukan - Lembaga Ilmu

Pengetahuan Indonesia (PPK-LIPI), 8(1), 37-52. https://doi.org/10.14203/jki.v8i1.21 